\title{
PROPOSAL
}

\section{PENGARUH KEDISIPLINAN TERHADAP HASIL BELAJAR SISWA di SD NEGERI KASSI KECAMATAN MANGGALA KOTA MAKASSAR}

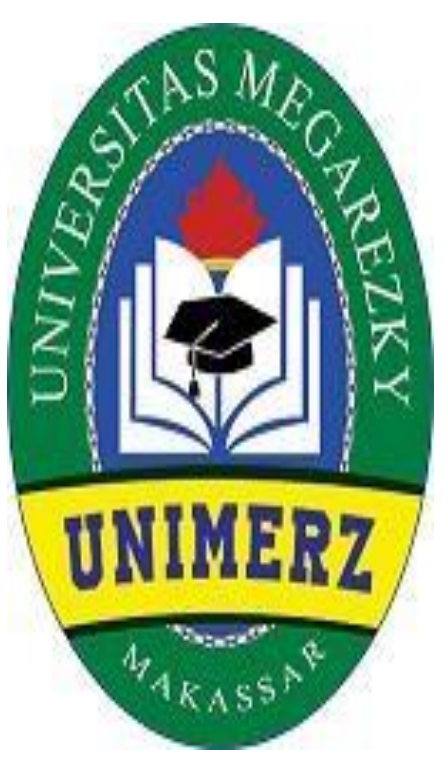

Diajukan Kepada Program Studi Pendidikan Guru Sekolah Dasar FKIP Universitas Megarezky Sebagai Salah Satu Syarat Untuk Mencapai Gelar Sarjana Pendidikan

\author{
SRI WAHYUNI \\ 17093188206047
}

PROGRAM STUDI PENDIDIKAN GURU SEKOLAH DASAR FAKULTAS KEGURUAN DAN ILMU PENDIDIKAN UNIVERSITAS MEGAREZKY 


\section{BAB I}

\section{PENDAHULUAN}

\section{A. Latar Belakang}

Berdasarkan Undang-undang RI No. 20 Tahun 2003 tentang Sistem Pendidikan Nasional menyebutkan bahwa:Pendidikan nasional berfungsi untuk mengembangkan kemampuan dan membentuk watak serta peradaban bangsa yang bermartabat dalam rangka mencerdaskan kehidupan bangsa, bertujuan untuk berkembangnya potensi siswa agar menjadi manusia yang beriman dan bertakwa kepada Tuhan Yang Maha Esa, berakhlak mulia, sehat, berilmu, cakap, kreatif, mandiri, dan menjadi warga negara yang demokratis serta bertanggung jawab.

Berdasarkan undang-undang sudah jelas bahwa pendidikan di Indonesia bukan hanya membentuk manusia yang berilmu dan cerdas namun memiliki akhlak yang mulia. Semua itu harapan yang pemerintah inginkan, membentuk manusia yang berkualitas melalui pendidikan.Maka dari itu mutu pendidikan harus selalu ditingkatkan.

Peningkatan mutu pendidikan di sekolah salah satunya melalui pencapaian hasil belajar siswa dalam pembelajaran. Kegiatan pembelajaran dipengaruhi oleh dua komponen yang penting yaitu guru dan siswa. Tugas guru menurut Hamalik terkait sebagai pengajar yaitu guru bertugas menyampaikan pelajaran kepada siswa agar siswa paham dengan baik dengan pengetahuan yang disampaikan. Terlihat jelas guru merupakan komponen pokok keberhasilan belajar siswakarena guru yang menyampaikan pengetahuan kepada siswa. Namun 3 hasil belajar siswa dipengaruhi oleh banyak faktor, baik dari dalam diri peserta didik atau dari lingkungan luar. Slameto menyatakan hasil belajar dipengaruhi oleh faktor internal (faktor jasmaniah, psikologis, dan kelelahan) dan faktor ekstern (faktor keluarga, sekolah dan masyarakat). Hasil belajar siswa dipengaruhi oleh banyak faktor, baik itu faktor dari dalam diri siswa sendiri atau faktor luar.

Kedisiplinan yang berkaitan dengan aturan dan ketertiban menjadi salah satu faktor yang mempengaruhi hasil belajar siswa. Kedisiplinan berasal 
dari kata disiplin yang mendapat imbuhan ke-an yang maknanya hal atau keadaan. Kedisiplinan merupakan salah satu sikap (perilaku) yang harus dimiliki oleh siswa. Siswa akan memperoleh hasil belajar yang memuaskan apabila siswa dapat berdisiplin terutama dalam belajar. Kedisiplinan tidak tumbuh dan ada begitu saja namun perlu di bina melalui latihan, pendidikan dan penanaman kebiasaan oleh guru dan orang tua.

Definisi disiplin sendiri menurut Prijodarminto dalam Tu'u yaitu "sebagai suatu kondisi yang tercipta dan terbentuk dari serangkaian perilaku yang menunjukkan nilai ketaatan, kepatuhan, kesetiaan atau keteraturan atau ketertiban". Jadi, kedisiplinan siswa ialah keadaan siswa yang menunjukkan nilai ketaatan, kepatuhan, kesetiaan atau keteraturan atau ketertiban.

Disiplin perlu disadarkan kepada setiap siswa sehingga siswa mempunyai kedisiplinan yang tinggi, telah dijelaskan oleh Tu'u bahwa dengan disiplin yang muncul karena kesadaran diri, siswa berhasil dalam belajarnya, tanpa disiplin yang baik suasana sekolah dan kelas menjadi kurang kondusif bagi kegiatan pembelajaran. Secara positif disiplin memberi dukungan lingkungan yang tenang dan tertib bagi proses pembelajaran, disiplin merupakan jalan bagi siswa untuk sukses dalam belajar dan kelak ketika bekerja, karena kesadaran akan pentingnya norma, aturan, kepatuhan dan ketaatan merupakan kunci kesuksesan seseorang.

Peningkatan kualitas pendidikan harus dimulai dengan memperbaiki karakteristik siswa sebagai peserta didik yang mempunyai peran penting dalam pembangunan nasional untuk kedepannya. Seorang peserta didik akan mengikuti proses pembelajaran dengan baik jika didasari dengan kedisiplinan yang kuat.. Dengan disiplin anak dapat belajar bertingkah laku sesuai tuntutan masyarakat dan dapat diterima di lingkungannya.

Kedisiplinan siswa yang baik akan mempengaruhi hasil belajar siswa. Disiplin berangkat sekolah dan mengikuti pelajaran, disiplin menaati peraturan yang ada di sekolah, dan disiplin mengerjakan tugas terutama tugas pekerjaan rumah. Berdasarkan informasi yang diperolah melalui wawancara dengan guru 
SDN Kassi para siswa memiliki tingkat kedisiplinan yang berbeda-beda, masih ada siswa kurang berdisiplin dalam mentaati peraturan sekolah. Khususnya ada beberapa anak yang persentase kehadirannya kurang. Masalah yang sering terjadi masih ada siswa yang tidak mengerjakan PR, terlambat masuk kelas dan guru masih menemukan siswa yang sering mencontek.

Ketika observasi dan wawancara juga menemukan bahwa hasil belajar siswa di SDN kassi masih ada siswa yang nilai ulangan hariannya kurang, masih ada siswa yang belum mencapai KKM. Namun, siswa yang nilai ulangannya kurang tersebut tidak semua juga kurang berdisiplin. Dari itu penulis tertarik untuk mengadakan penelitian terkait kedisiplinan siswa, seberapa besar "Pengaruh kedisiplinan siswa di SDN Kassi Kecamatan Manggala Kota Makassar terhadap hasil belajar.

\section{B. Rumusan Masalah}

Berdasarkan latar belakang penelitian, identifikasi dan batasan masalah tersebut di atas, maka rumusan masalah penelitian ini yaitu sebagai berikut.

Apakah ada pengaruh antara kedisiplinan terhadap hasil belajar siswa di SD Negeri Kassi Kecamatan Manggala Kota Makassar?

\section{Tujuan Penelitian}

Penelitian ini terdiri atas dua tujuan yaitu tujuan umum dan tujuan khusus. Adapun tujuan umum dan tujuan khusus dilaksanakannya penelitian ini adalah sebagai berikut:

1. Tujuan Umum

Untuk menganalisis pengaruh kedisiplinan terhadap hasil belajar siswa di SD Negeri Kassi Kecamatan Manggala Kota Makassar.

2. Tujuan Khusus

Untuk menganalisis seberapa besar signifikan pengaruh kedisiplinan terhadap hasil belajar siswa di SD Negeri Kassi Kecamatan Manggala Kota Makassar. 


\section{Manfaat Penelitian}

1. Manfaat Teoretis

Penelitian ini diharapkan dapat memperluas pengetahuan dan menambah referensi di bidang pendidikan dan memberikan informasi tentang pengaruh kedisiplinan siswa terhadap hasil belajar siswa dan Penelitian ini dapat dijadikan sumber bacaan dan bahan kajian lebih lanjut bagi penulis selanjutnya khususnya di bidang pendidikan.

2. Manfaat Praktis

Secara praktis, penelitian ini memberikan manfaat bagi penulis, siswa, guru, dan pihak sekolah. Manfaat tersebut antara lain sebagai berikut:

a. Bagi Guru

Hasil penelitian ini diharapkan dapat menambah masukan bagi guru untuk meningkatkan kedisiplinan siswa untuk meningkatkan hasil belajar siswa.

b. Bagi siswa

Penelitian ini dapat dijadikan sebagai bahan masukan untuk meningkatkan kedisiplinan siswa di sekolah. Serta dapat menjadi masukan meningkatkan hasil belajar siswa.

c. Bagi Sekolah

Hasil penelitian ini diharapkan dapat memberikan informasi dan membantu pihak sekolah untuk meningkatkan mutu pendidikan sehubungan dengan hasil belajar siswa. 


\section{BAB II}

\section{KAJIAN PUSTAKA, KERANGKA PIKIR DAN \\ HIPOTESIS TINDAKAN}

\section{A. Kajian Pustaka}

\section{Pengertian Kedesiplinan}

Kedisiplinan berasal dari kata dasar disiplin yang mendapat imbuhan ke- an. Makna imbuhan ke-an dijelaskan oleh Sugiarto kata yang mendapat imbuhan ke-an mengacu ke hal atau keadaan. Ditegaskan kembali oleh Hadi makna imbuhan ke-an mengandung beberapa makna menurut kata yang mendapat imbuhan, antara lain hal atau keadaan, agak atau terlalu, terkena, menyerupai dll. Kedisiplinan disini mendapat imbuhan ke-an yang bermakna hal atau keadaan.

Disiplin dalam Bahasa Indonesia seringkali terkait dan menyatu dengan istilah tata tertib dan ketertiban. Istilah ketertiban mempunyai arti kepatuhan seseorang dalam mengikuti peraturan atau tata tertib karena didorong atau disebabkan oleh sesuatu yang datang dari luar dirinya. Sebaliknya, istilah disiplin sebagai kepatuhan dan ketaatan yang muncul karena adanya kesadaran dan dorongan dari dalam diri orang itu. Istilah tata tertib berarti perangkat peraturan yang berlaku untuk menciptakan kondisi yang tertib dan teratur .

Prijodarminto dalam Tu'u menjelaskan bahwa "disiplin sebagai suatu kondisi yang tercipta dan terbentuk dari serangkaian perilaku yang menunjukkan nilai ketaatan, kepatuhan, kesetiaan atau keteraturan atau ketertiban". dalam Mujiati) memberikan pengertian disiplin yaitu "Disiplin adalah suatu keadaan tertib di mana orang-orang yang tergabung dalam suatu organisasi tunduk pada peraturan-peraturan yang telah ada dengan rasa senang hati”. 
Berdasarkan uraian di atas, maka dapat disimpulkan bahwa kedisiplinan adalah keadaan sikap atau perilaku seseorang yang sesuai dengan aturan atau tata tertib yang berlaku sehingga tercipta ketertiban dan keteraturan. Dengan adanya kedisiplinan yang berdasarkan dorongan dan kesadaran yang muncul dalam hatinya serta dilakukan secara teratur tanpa adanya paksaan atau tekanan dari pihak manapun akan membentuk kedisiplinan yang membekas. Kedisiplinan tersebut dapat membantu siswa untuk mewujudkan tujuan yang telah ditetapkan sekaligus membantu siswa mencapai tujuan secara maksimal.

\section{Perlunya Disiplin}

Disiplin diperlukan oleh siapapun dan di manapun, begitu pula siswa. Dengan adanya disiplin siswa dapat mencapai hasil belajar yang optimal. Dunham dalam Ehiane "effective discipline helps in the achievement of goals, expectation and responsibility in students". Artinya disiplin yang efektif membantu dalam pencapaian tujuan, harapan dan tanggung jawab pada siswa. Jadi disiplin membantu siswa untuk mencapai tujuannya, tujuan siswa dalam belajar adalah mencapai hasil belajar yang memuaskan. Selain itu, disiplin berperan penting membentuk individu yang bertanggung jawab.

Disiplin memang memegang peran penting dikehidupan setiap individu bahkan penting untuk seorang siswa. Siswa perlu mempunyai sikap disiplin di sekolah bahkan di dalam belajar. Menurut Tu'u disiplin penting karena alasan berikut ini:

a. Dengan disiplin yang muncul karena kesadaran diri, siswa berhasil dalam belajarnya. Sebaliknya siswa yang sering melanggar peraturan sekolah pada umumnya terhambat optimalisasi potensi dan prestasinya.

b. Tanpa disiplin yaang baik, suasana sekolah dan kelas menjadi kurang kondusif bagi kegiatan pembelajaran. Secara positif disiplin memberi dukungan bagi proses pembelajaran.

c. Orang tua senantiasa berharap di sekolah anak-anak dibiasakan dengan 
norma-norma, nilai kehidupan dan disiplin. Dengan demikian anakanak dapat menjadi individu yang tertib, teratur dan disiplin.

d. Disiplin merupakan jalan bagi siswa untuk sukses dalam belajar dan kelak ketika bekerja. Kesadaran akan pentingnya norma, aturan, kepatuhan dan ketaatan merupakan prasyarat kesuksesan seseorang.

Rachman dalam Tu'u juga menyatakan pentingnya disiplin bagi siswa, yaitu sebagai berikut: (1) Memberi dukungan bagi terciptanya perilaku yang tidak menyimpang, membantu siswa memahami dan menyesuaikan diri dengan tuntutan lingkungan, (2) cara menyelesaikan tuntutan yang ingin ditunjukkan peserta didik terhadap lingkungannya, untuk mengatur keseimbangan keinginan individu satu dengan individu lainnya, (3) menjauhi siswa melakukan hal-hal yang dilarang sekolah, mendorong siswa melakukan hal-hal yang baik dan benar, (4) peserta didik belajar hidup dengan kebiasaan-kebiasaan yang baik, positif dan bermanfaat baginya dan lingkungannya, (5) terakhir kebiasaan baik itu menyebabkan ketenangan jiwanya dan lingkungannya.

Selanjutnya Parker menjelaskan pentingnya disiplin untuk menjaga anak-anak tetap terjaga dan aman, mengajarkan anak untuk memikirkan orang lain termasuk orang tuanya, memberikan sebuah kondisi yang bisa diprediksi dan karenanya aman bagi mereka jika berada di sana, membantu anak- anak mengembangkan kemandirian yang konstruktif, memperjelas perbedaan antara perilaku yang diterima dan yang tidak diterima, menunjukkan bahwa setiap perbuatan memiliki akibat, membantu agar anak dengan mudah berhadapan dengan beragam kelompok, misalnya keluarga atau sekolah.

Berdasarkan uraian di atas maka dapat disimpulkan bahwa disiplin sangat penting bagi setiap siswa. Disiplin yang tumbuh secara sadar akan membentuk sikap, perilaku dan tata kehidupan yang teratur yang akan menjadikan siswa sukses ketika belajar. Siswa yang disiplin akan mencapai hasil belajar yang baik. Siswa yang mempunyai aturan dan tata tertib dalam 
baik di sekolah atau di rumah serta mentaati aturan tersebut akan membuat siswa menjadi terbiasa dan tertib.

\section{Faktor-Faktor Yang Mempengaruhi Belajar}

Disiplin itu merupakan sesuatu yang penting, disiplin juga memiliki berbagai fungsi bagi setiap individu. Fungsi disiplin menurut Tu'u ada enam, yaitu menata kehidupan bersama, membangun kepribadian, melatih kepribadian, pemaksaan, hukuman, dan menciptakan lingkungan yang kondusif. Disiplin memiliki fungsi yang beragam dan disiplin yang utama adalah melatih dan membentuk kepribadian.

Fungsi disiplin yang pertama adalah menata kehidupan. Setiap individu pasti membutuhkan orang lain, seseorang tidak bisa hidup sendiri. setiap orang pasti berhubungan dengan orang lain, maka setiap orang yang hidup dikatakan makhluk sosial. Dalam hidup bersosial atau hidup berdampingan perlu adanya norma dan nilai untuk mengatur semua kehidupan dan kegiatan yang dilakukan setiap orang supaya dapat berjalan lancar tidak ada perselisihan. Disiplin disini memiliki peran untuk menyadarkan semua orang bahwa harus saling menghargai dan menghormati sesama dalam kehidupan.

Membangun kepribadian adalah fungsi disiplin yang kedua. Kepribadian adalah sifat, tingkah laku dan pola hidup seseorang yang tercermin dalam kehidapannya sehari-hari. Kepribadian terbentuk didalam lingkunag keluarga, sekolah dan masyarakat. Disiplin yang diterapkan di lingkungan tersebut akan membentuk kepribadian seseorang. Kedisiplinan akan membuat seseorang terbiasa untuk mengikuti dan menaati aturan yang kemudian kebiasaan itu akan membekas pada diri seseorang tersebut. Kebiasaan tersebut kemudian akan menjadi kepribadiannya.

Kepribadian tidak begitu saja terbentuk namun perlu dilatih. Fungsi disiplin yang ketiga adalah melatih kepribadian. Sikap, tingkah laku dan pola hidup yang baik tidak semata-mata terbentuk begitu saja dalam waktu singkat. Semua itu dibentuk dan melalui proses latihan yang panjang. 
Berusaha untuk selalu berdisiplin adalah bentuk latiahan yang nanti akan membentuk kepribadian.

Pemaksaan dan hukuman adalah fungsi disiplin yang selanjutnya. Disiplin yang dipaksa sebenarnya tidak baik dan biasanya akan menyebabkan pengaruh negatif bagi orang tersebut. Namun dengan pendampingan guru dan orang tua dalam pemaksaan dan pembiasaan akan melatih siswa untuk berdisiplin dan menyadarkan bahwa disiplin penting. Hukuman sendiri biasanya dibentuk untuk memberikan sanksi kepada pelanggar tata tertib atau aturan. Aturan dan tata tertib berisi hal-hal positif yang harus dilaksanakan atau dipatuhi. Hukuman sendiri dapat mendorong siswa untuk menaati dan mematuhi tata tertib yang ada. Namun hukuman yang diberikan harus ada nilai pendidikan agar siswa dapat sadar dan belajar bukan membawa hal yang negative dan trauma bagi siswa.

Menciptakan lingkungan kondusif adalah salah satu fungsi disiplin yang lain. Sekolah adalah lingkungan pendidikan dimana dilaksanakannnya proses belajar mengajar. Sekolah sebagai lingkungan pendidikan harus menjamin terselenggaranya proses belajar yang baik dengan kondisi yang baik pula. Kondisiyang baik meliputi kondisi aman, tentram, tenang, tertib dan teratur, saling menghargai dan hubungan pergaulan ynag baik. Belajar dengan lingkungan yang kondusif akan memberikan kenyamanan dan belajar akan lebih berhasil dan optimal.

\section{Faktor-faktor yang Memepengaruhi Disiplin}

Kedisiplinan siswa dapat terbentuk dan terbina melalui berbagai cara, disiplin itu tidak terbentuk begitu saja perlu latihan dan pembinaan serta diri kemauan siswa. Berdasarkan penuturan Tu'u disiplin dipengaruhi oleh beberapa hal, yaitu kesadaran diri, pengikutan dan ketaatan, alat pendidikan, hukuman, teladan, lingkungan yang berdisiplin, dan latihan berdisiplin. Ketujuh faktor tersebut merupakan faktor-faktor yang mempengaruhi seseorang berdisiplin baik dilingkungan sekolah atau lingkungan keluarga. 
Faktor kesadaran diri adalah faktor dimana seseorang memahami dan mengerti bahwa disiplin penting bagi kebaikan dan keberhasilan dirinya. Ketika seseorang atau siswa menyadari bahwa disiplin penting maka siswa akan selalu senantiasa berdisiplin yang nantinya hasil belajar siswa di rumah atau di sekolah menjadi lebih baik. Faktor kedua, pengikutan dan ketaatan dimana faktor ini kelanjutan dari kesadaran diri. Setelah siswa telah memiliki kesadaran diri bahwa disiplin penting maka siswa akan melakukan sikap atau perilaku yang taat akan aturan. Hal ini merupakan pengikutan atau ketaatan, artinya siswa mengikuti atau menaati peraturan-peraturan yang berlaku.

Alat pendidikan merupakan faktor selanjutnya yang mempengaruhi disiplin. Alat pendidikan dimaksudkan untuk mempengaruhi, mengubah, membina dan membentuk perilaku yang sesuai dengan nilai-nilai yang ditentukan atau diajarkan. Dengan alat pendidikan, disiplin siswa dapat dibentuk dan dilatih sehingga siswa mempunyai kedisiplinan yang baik. Alat pendidikan biasanya diikuti dengan hukuman. Hukuman digunakan sebagai upaya menyadarkan, mengoreksi dan meluruskan yang salah sehingga siswa dapat kembali pada perilaku yang sesuai harapan.

Selanjutnya, faktor teladan mempengaruhi disiplin siswa. teladan atau contoh akan lebih bermakna dibandingkan kata-kata nasehat atau peringatan. Teladan yang dilakukan oleh orang tua, guru atau kepala sekolah akan mempengaruhi siswa secara tidak langsung. Siswa lebih sering mencontoh hal-hal ynag dilakukan oleh orang tua atau gurunya. Maka dari itu, orang tua, guru atau kepala sekolah perlu memberikan teladan yang baik terutama ketika didepan siswa.

Faktor yang lain adalah lingkungan yang berdisiplin. Siswa juga dapat dipengaruhi oleh lingkungannya. Lingkungan sangat mempengaruhi siswa karena siswa dimana tempat siswa bergaul dan berinteraksi. Ketika lingkungan siswa tidak disiplin maka siswa akan terpengaruh untuk tidak berdisiplin, sebaliknya lingkungan disiplin akan mempengaruhi siswa untuk 
disiplin. Siswa akan terbawa berdisiplin bila lingkungannya sudah disiplin. Ketika di lingkungan rumah yang

Faktor yang terakhir adalah latihan berdisiplin. Disiplin dapat dicapai dan dibentuk melalui latihan dan kebiasaan. Artinya, melakukan disiplin secara berulang-ulang dan membiasakannya dalam praktik-praktik disiplin sehari-hari. Praktik yang dilakukan sehari-hari akan membuat siswa terbiasa, dan akhirnya siswa dapat disiplin. Dengan latihan juga, siswa akan tebiasa dan membiasakan diri sehingga dalam diri siswa akan terbentuk disiplin.

\section{Aspek-aspek Kedisiplinan}

Menurut Arikunto dalam Aulia kedisiplinan siswa dapat dilihat dari 3 aspek yaitu, aspek disiplin siswa di lingkungan keluarga, aspek disiplin siswa di lingkungan sekolah, dan aspek disiplin siswa di lingkungan pergaulan.

Disiplin di lingkungan keluarga adalah peraturan dirumah mengajarkan anak apa yang harus dan apa yang boleh dilakukan di rumah atau dalam hubungan dengan anggota keluarga. Disiplin keluarga mempunyai peran penting agar anak segera belajar dalam hal perilaku. Lingkungan keluarga sering disebut lingkungan pertama didalam pendidikan dan sangat penting untuk membetuk pola kepribadian anak, karena di keluarga anak pertama kali berkenalan dengan nilai dan norma. Aspek disiplin di lingkungan keluarga, meliputi:

a. Mengerjakan tugas sekolah di rumah

b. Mempersiapkan keperluan sekolah dirumah.

Selain disiplin di lingkungan keluarga selanjutnya adalah disiplin di lingkungan sekolah. Disiplin di lingkungan sekolah adalah peraturan, peraturan ini mengatakan pada anak apa yang harus dan apa yang tidak boleh dilakukan sewaktu dilingkungan sekolah. Disiplin sekolah merupakan hal yang sangat penting dalam peraturan dan tata tertib yang ditunjukan pada siswa. Apabila disiplin sekolah telah menjadi kebiasaan belajar, maka 
nantinya siswa benar-benar menganggap kalau belajar disekolah adalah merupakan suatu kebutuhan bukan sebagai kewajiban atau tekanan. Aspek disiplin siswa di lingkungan sekolah, meliputi :

a. Sikap siswa dikelas

b. Kehadiran siswa

c. Melaksanakan tata tertib di sekolah.

Aspek disiplin siswa di lingkungan pergaulan yaitu aspek dimana siswa bermain dan berinteraksi dengan teman dan masyarakat. Maksud disiplin pergaulan sendiri adalah peraturan lapangan bermain terutama dipusatkan pada permainan dan olah raga. Peraturan itu juga mengatur tingkah laku kelompok. Peraturan disini mempunyai nilai pendidikan, sebab peraturan memperkenalkan pada anak prilaku yang disetujui anggota kelompoknya. Aspek disiplin siswa di lingkungan pergaulan, meliputi :

a. Yang berhubungan dengan pinjam meminjam

b. Yang berhubungan dengan disiplin waktu.

Demikian aspek-aspek yang dikemukakan oleh Arikunto. Dari uraian di atas dapat disimpulkan bahwa aspek-aspek kedisiplinan siswa dapat dilihat dari aspek disiplin di lingkungan keluarga, di lingkungan sekolah dan di lingkungan pergaulan. Dalam lingkungan tersebut kedisiplinan siswa dapat dilihat, serta lingkungan dapat membentuk kedisiplinan siswa.

\section{Indikator Kedisiplinan Siswa}

Dari aspek-aspek disiplin menurut Arikunto yang telah diuraikan, maka dapat diambil lima indikator kedisiplinan siswa sebagai berikut:

a. Mengerjakan tugas sekolah di rumah

Mengerjakan tugas sekolah dirumah maksudnya adalah jika ada pekerjaan rumah (PR) dari guru maka siswa selalu mengerjakannya dirumah secara individu maupun kelompok dan bertanya kepada bapak atau ibunya.

b. Mempersiapkan keperluan sekolah di rumah 
Mempersiapkan keperluan sekolah dirumah maksudya adalah setiap sore atau malam hari siswa selalu mempersiapkan perlengkapan belajar misalnya buku tulis, buku paket, dan alat tulis yang akan dibawa kesekolah.

c. Sikap siswa di kelas

Sikap siswa dikelas maksudnya adalah pada saat guru menerangkan materi pelajaran maka siswa memperhatikannya dan tidak membuat kegaduhan di kelas serta jika ada tugas dari guru maka siswa akan langsung mengerjakannya.

d. Kehadiran Siswa

Kehadiran siswa maksudnya adalah siswa tidak terlambat pada saat pembelajaran akan dimulai maka siswa akan datang kekelas lebih awal dan siswa tidak membolos pada saat pembelajaran dimulai.

e. Melaksanakan tata tertib di sekolah

Mengerjakan tata tertib disekolah maksudnya semua aturan yang tetulis baik mengenai seragam maupun sikap disekolah harus ditaati dan patuhi.

Tu'u dalam penelitiannya mengenai disiplin mengemukakan bahwa indikator yang menunjukkan pergeseran atau perubahan hasil belajar siswa sebagai kontribusi mengikuti dan menaati peraturan sekolah meliputi: dapat mengatur waktu belajar di rumah, rajin dan teratur belajar, perhatian yang baik saat belajar di kelas dan ketertiban diri saat belajar di kelas.

Sejalan dengan pendapat Khafid alam penelitiannya yang membagi indikator kedisiplinan yang menjadi beberapa indikator sebagai berikut: ketaatan terhadap tata tertib sekolah, ketaatan terhadap kegiatan belajar di sekolah, ketaatan dalam mengerjakan tugas-tugas pelajaran, dan ketaatan terhadap kegiatan belajar di rumah. 
Berdasarkan uraian di atas, maka dalam penelitian ini penulis membagi indikator kedisiplinan siswa menjadi lima macam, yaitu sebagai berikut:

1) Dsiplin berangkat sekolah,

2) Disiplin mengikuti pembelajaran di sekolah,

3) Disiplin mengerjakan tugas,

4) Disiplin belajar di rumah,

5) Disiplin menaati tata tertib sekolah.

\section{Pengertian Belajar}

Pakar pendidikan telah banyak mengemukakan pengertian tentang belajar, salah satunya Slavin dalam Rifa'i dan Anni menyatakan bahwa belajar merupakan perubahan individu yang disebabkan oleh pengalaman. Menurut Gage dan Berliner dalam Rifa'i dan Anni menyatakan bahwa belajar merupakan proses dimana suatu organisme mengubah perilakunya karena hasil dari pengalaman. Sejalan dengan Cronbach dalam Suprijono menyatakan bahwa belajar adalah perubahan perilaku sebagai hasil dari pengalaman.

Pengertian belajar secara psikologis menurut Slameto merupakan suatu proses perubahan yaitu perubahan tingkah laku sebagai hasil dari interaksi dengan lingkungannya. Drs. Slameto kemudian mendefinisikan belajar sebagai suatu proses usaha seseorang untuk memperoleh suatu perubahan tingkah laku yang baru secara keseluruhan, sebagai hasil pengalamannya sendiri dalam interaksi dengan lingkungannya. Hal ini kurang lebih sama dengan menurut Morgan dalam Suprijono belajar adalah perubahan perilaku yang bersifat permanen sebagai hasil dari pengalaman.

Berdasarkan beberapa pendapat tentang pengertian belajar tersebut, dapat disimpulkan bahwa belajar merupakan suatu usaha sadar yang dilakukan seseorang yang mengakibatkan perubahan tingkah laku yang tetap atau permanen sebagai hasil dari latihan atau pengalaman dalam interaksinya dengan lingkungan. Perubahan tersebut tidak hanya bertambahnya 
pengetahuan, tetapi terwujud dalam sikap, keterampilan, kecakapan, kemampuan, tingkah laku, kepribadian, dan lain- lain.

\section{Hasil Belajar}

Winkel dalam Purwanto mendefinisikan hasil belajar merupakan perubahan yang mengakibatkan manusia berubah dalam sikap dan tingkah lakunya. Rifa'i dan Anni menjelaskan pengertian hasil belajar secara singkat yaitu "hasil belajar merupakan perubahan perilaku yang diperoleh peserta didik setelah mengalami kegiatan belajar”.

Hasil belajar dapat berupa ilmu pengetahuan, namun tidak hanya pengetahuan yang diperoleh setiap individu dalam belajar. Menurut Gagne dalam Suprijono, hasil belajar siswa berupa informasi verbal, keterampilan intelektual, strategi kognitif, keterampilan motorik, dan sikap. Bentuk hasil belajar siwa menurut Gagne tersebut tidak hanya pengetahuan saja. Namun hasil belajar dapat berupa informasi verbal, keterampilan dan sikap.

Informasi verbal yaitu kapabilitas mengungkapkan pengetahuan dalam bentuk bahasa, baik lisan maupun tertulis. Kemampuan merespons secara spesifik terhadap rangsangan spesifik. Kemampuan tersebut tidak memerlukan masnipulasi simbol, pemecahan masalah maupun penerapan aturan. Untuk keterampilan intelektual yaitu kemampuan mempresentasikan konsep dan lambang.

Keterampilan intelektual terdiri dari kemampuan mengategorisasi, kemampuan analitis-sintesis fakta-konsep dan mengembangkan prinsipprinsip keilmuan. Keterampilan intelektual merupakan kemampuan melakukan aktivitas kognitif bersifat khas.

Hasil belajar yang berupa strategi kognitif yaitu kecakapan menyalurkan dan mengarahkan aktivitas kognitifnya sendiri. Kemampuan ini meliputi penggunaan konsep dan kaidah dalam memecahkan masalah. Hasil belajar yang berupa keterampilan motorik yaitu kemampuan melakukan gerak jasmani dalam urusan dan koordinasi, sehingga terwujud gerak 
jasmani. Terakhir, hsail belajar berupa sikap adalah kemampuan menerima atau menolak obyek berdasarkan penilaian terhadap obyek tersebut. Sikap berupa kemampuan menginternalisasi dan eksternalisasi nilai-nilai. Sikap merupakan kemampuan menjadikan nilai-nilai sebagai standar perilaku.

Sementara Bloom dalam Sudjana berpendapat bahwa hasil belajar itu mencakup tiga ranah, yakni ranah kognitif, ranah afektif, dan ranah psikomotorik. Ranah kognitif berkenaan dengan hasil belajar intelektual yang terdiri dari enam aspek, yakni pengetahuan atau ingatan, pemahaman, aplikasi, analisis, sintesis, dan evaluasi. Kedua aspek pertama disebut kognitif tingkat rendah dan keempat aspek berikutnya termasuk kognitif tingkat tinggi. Ranah afektif berkenaan dengan sikap yang terdiri dari lima aspek, yakni penerimaan, jawaban atau reaksi, penilaian, organisasi, dan internalisasi. Ranah psikomotoris berkenaan dengan hasil belajar ketrampilan dan kemampuan bertindak. Ada enam aspek ranah psikomotoris, yakni (a) gerakan refleks, (b) ketrampilan gerakan dasar, (c) kemampuan perceptual, (d) keharmonisan atau ketepatan, (e) gerakan ketrampilan kompleks, dan (f) gerakan ekspresif dan interpretatif. Ketiga ranah tersebut menjadi objek penilaian hasil belajar. Diantara ketiga ranah tersebut, ranah kognitiflah yang paling banyak dinilai oleh para guru di sekolah karena berkaitan dengan kemampuan para siswa menguasai isi bahan pengajaran.

Berdasarkan pengertian hasil belajar tersebut dapat disimpulkan hasil belajar merupakan perubahan tingkah laku dan sikap pada individu setelah melakukan kegiatan belajar. Hasil belajar yang diperoleh individu yaitu berupa pengetahuan, keterampilan dan sikap yang ketiganya termasuk dalam tiga ranah. Ketiga ranah tersebut umumnya merupakan objek penilaian hasil belajar dalam kegiatan belajar. Ranah kognitif yang umum digunakan oleh guru berkaitan dengan pengetahuan akademik.

\section{Faktor-faktor yang Mempengaruhi Hasil Belajar}

Belajar yang efektif sangat dipengaruhi oleh beberapa faktor. Dalam bukunya, Hamalik (2013: 32,33) mengatakan belajar efektif dipengaruhi oleh 
faktor-faktor kondisioanal yang ada, ada sepuluh faktor kondisional tersebut yaitu pertama faktor kegiatan, penggunaan dan ulangan; kedua latihan; kepuasan; mengetahui berhasil atau tidak; faktor asosiasi; pengalaman masa lampau; kesiapan belajar; minat dan usaha; selanjutnya faktor-faktor fisiologis; dan terakhir intelegensi.

Faktor kegiatan, penggunaan dan ulangan. Apapun yang telah dipelajari perlu digunakan secara prak tis dan diadakan ulangan secara berlanjut di bawah kondisi yang serasi, sehingga penguasaan hasil belajar menjadi lebih mantap. Kedua, belajar memerlukan latihan. Melalui relearning, recalling, dan reviewing, pelajaran yang terlupakan dapat dikuasai kembali dan pelajaran yang belum dikuasai akan dapat lebih mudah dipahami.

Ketiga, belajar siswa lebih berhasil, belajar akan lebih berhasil jika siswa merasa berhasil dan mendapat kepuasannya. Belajar hendaknya dilakukan dalam suasana yang menyenangkan. Maka hasil yang diperoleh akan baik dan optimal. Keempat, Siswa perlu mengetahui apakah ia berhasil atau gagal dalam belajarnya. Keberhasilan akan memberi kepuasan dan mendorong belajar lebih baik, sedangkan kegagalan akan membuat frustasi.

Faktor asosiasi, faktor kondisional yang kelima mempengaruhi belajar. Faktor ini manfaatnya besar dalam belajar karena semua pengalaman belajar antara yang lama dan yang baru diasosiasikan secara berurut, sehingga menjadi satu kesatuan pengalaman. Kemudian siswa setelah mengasosiasikan akan mendapat pemahaman yang utuh. Keenam, pengalaman masa lampau (bahan apersepsi) dan pengertian yang dimiliki siswa. Pengalaman dan pengertian itu menjadi dasar untuk menerima pengalaman-pengalaman baru dan pengertian- pengertian baru.

Selanjutnya, faktor kesiapan belajar. Murid yang siap belajar akan dapat melakukan kegiatan belajar lebih mudah dan lebih berhasil. Siswa yang kurang siap dalam belajar maka tidak akan berhasil atau tetinggal dengan siswa yang lain. Selain kesiapan belajar faktor minat dan usaha juga 
mempengaruhi hasil belajar. Belajar dengan minat akan mendorong siswa belajar lebih baik daripada belajar tanpa minat. Namun, minat tanpa usaha yang baik maka belajar sulit untuk berhasil.

Selanjutnya yang terakhir faktor-faktor fisiologis dan faktor intelegensi. Faktor fisiologis artinya kondisi badan siswa sangat berpengaruh dalam proses belajar. Badan yang lemah akan menurunkan perhatian siswa yang akhirnya belajar tidak sempurna. Sedangkan faktor intelegensi, berkaitan dengan kecerdasan siswa. Siswa yang cerdas akan lebih berhasil dalam kegiatan belajar daripada yang kurang cerdas. Siswa yang cerdas akan lebih mudah menangkap dan memahami materi daripada siswa yang kurang cerdas.

Menurut Rifa'i dan Anni, faktor-faktor yang mempengaruhi belajar adalah kondisi internal dan eksternal peserta didik. Kondisi internal mencakup kondisi fisik, seperti kesehatan organ tubuh; kondisi psikis, seperti kemampuan intelektual, emosional; dan kondisi sosial, seperti kemampuan bersosialisasi dengan lingkungan. Oleh karena itu kesempurnaan dan kualitas kondisi internal yang dimiliki oleh peserta didik akan berpengaruh terhadap kesiapan, proses, dan hasil belajar.

Beberapa faktor eksternal yaitu variasi dan tingkat kesulitan materi belajar (stimulus) yang dipelajari (direspon), tempat belajar, iklim, suasana lingkungan, dan budaya belajar masyarakat akan mempengaruhi kesiapan, proses, dan hasil belajar. Jadi belajar yang berhasil mempersyaratkan pendidik memperhatikan kemampuan internal peserta didik dan situasi stimulus yang berada di luar peserta didik. Dengan kata lain belajar tipe kemampuan baru harus dimulai dari kemampuan yang telah dipelajari sebelumnya dan menyediakan situasi eksternal yang bervariasi.

Selanjutnya Slameto mengemukakan faktor-faktor yang yang mempengaruhi hasil belajar dapat digolongkan menjadi dua, yaitu: 
Pertama, Faktor internal adalah faktor yang berasal dari individu itu sendiri. Faktor internal terdiri atas faktor jasmaniah, faktor psikologis, dan faktor kelelahan. Faktor jasmaniah meliputi segala sesuatu yang berhubungan dengan keaadaan jasmani. Hal-hal yang perlu diperhatikan sehubungan dengan faktor jasmani diantaranya kesehatan dan cacat tubuh.

Faktor psikologis dalam belajar meliputi intelegensi, perhatian, minat, bakat, motif, kematangan, dan kesiapan. Untuk faktor kelelahan dalam belajar dapat dibedakan menjadi dua macam, yaitu kelelahan jasmani dan kelelahan rohani (bersifat psikis). Kelelahan jasmani dapat terlihat dengan adanya kecenderungan untuk membaringan tubuh. Sedangkan kelelahan rohani dapat terlihat dengan adanya kelesuan dan kebosanan, sehingga minat dan dorongan untuk belajar hilang. Kelelahan baik secara jasmani maupun rohani dapat dihilangkan dengan cara istirahat, tidur, melakukan variasi dalam belajar, olahraga secara teratur, dan lain-lain.

Kedua, Faktor eksternal adalah faktor yang berasal dari luar diri individu. Faktor eksternal dapat dikelompokkan menjadi tiga, yaitu faktor keluarga, faktor sekolah, dan faktor masyarakat. Uraian selangkapnya sebagai berikut.

Faktor keluarga yang mempengaruhi belajar meliputi cara orang tua dalam mendidik anak, relasi antar anggota keluarga, suasana rumah, sosial ekonomi keluarga, pengertian orang tua, dan latar belakang kebudayaan. Selanjutnya, faktor sekolah yang mempengaruhi belajar mencakup metode mengajar, relasi guru dengan siswa, relasi siswa dengan siswa, disiplin sekolah, alat pelajaran, waktu sekolah, strandar pelajaran, keadaan gedung, metode belajar dan tugas rumah.

Dalam disiplin sekolah dijelaskan agar siswa belajar lebih maju, siswa harus disiplin di dalam belajar baik di sekolah, di rumah, dan di perpustakaan. Agar siswa disiplin haruslah guru beserta stafnya yang lain disiplin. Kemudian fakor masyarakat merupakan faktor eksternal yang juga berpengaruh terhadap belajar siswa. Faktor masyarakat yang mempengaruhi 
belajar siswa antara lain kegiatan siswa dalam masyarakat, media massa seperti TV, teman bergaul, dan bentuk kehidupan masyarakat di sekitar siswa.

Faktor-faktor yang mempengaruhi hasil belajar sesuai pendapat para ahli digolongkan menjadi dua, faktor internal dan eksternal. Hasil belajar akan tercapai dengan memuaskan dan maksimal apabila faktor-faktor tersebut diperhatikan oleh guru dan orang tua serta pihak sekolah.

\section{Pengaruh Kedisiplinan Siswa Terhadap Hasil Belajar}

Hasil belajar dipengaruhi oleh kedisiplinan siswa dalam belajar dan disiplin di sekolah. Kedisiplinan siswa dalam hal ini merupakan keadaan siswa yang taat dan teratur sesuai aturan. Ketika di sekolah memang disiplin perlu di perhatikan. Dengan keadaan siswa yang disiplin akan mendukung berjalannya belajar di sekolah dengan lancer. Dalam pembelajaran di kelas, disiplin akan membuat suasana belajar lebih kondusif dan tenang.

Pembelajaran di kelas akan berjalan sesuai dengan harapan bila guru dan siswa dapat saling bekerja sama atau saling mendukung. Pembelajaran yang kondusif tercipta apabila siswa berdisiplin saat pembelajaran sedang berlangsung. Siswa yang disiplin di kelas dengan tidak mengganggu teman, mendengarkan penjelasan guru, mengerjakan tugas dengan baik maka siswa akan mendapat hasil yang maksimal dalam belajarnya. Jadi, hasil belajar secara tidak langsung dipengaruhi oleh kedisiplinan siswa.

Kedisiplinan siswa memiliki pengaruh yang besar terhadap hasil belajar siswa karena dengan adanya disiplin, siswa teratur dan tertib saat di sekolah dan saat belajar. Bagi siswa yang sudah menerapkan disiplin, mereka akan selalu ingat dengan kewajibannya dan tanggung jawabnya untuk belajar yang rajin setiap harinya. Hal ini dikarenakan mereka sudah menyadari akan pentingnya belajar. Sebaliknya bagi siswa yang kurang menerapkan kedisiplinan, mereka menganggap belajar merupakan sebuah paksaan atau tekanan bagi dirinya. Belajar yang berlandaskan paksaan tidak akan bertahan lama. Akan tetapi, ada sebagian anak walaupun awalnya mendapat paksaan 
dalam menerapkan disiplin dan akhirnya anak menyadari akan pentingnya belajar dan kewajiban belajar untuk mendapatkan hasil belajar yang memuaskan.

\section{B. Kerangka Pikir}

H.asil belajar merupakan perubahan tingkah laku dan sikap pada individu setelah melakukan kegiatan belajar. Hasil belajar yang diperoleh individu yaitu berupa pengetahuan, keterampilan dan sikap yang ketiganya termasuk dalam tiga ranah. Ketiga ranah tersebut umumnya merupakan objek penilaian hasil belajar dalam kegiatan belajar. Dalam penelitian ini difokuskan pada ranah kognitif, jadi yang diteliti hanya ranah kognitif yang berkaitan dengan nilai akademik siswa di sekolah.

Kualitas pendidikan di sekolah salah satunya ditentukan oleh hasil belajar siswa. Pada dasarnya hasil belajar dipengaruhi oleh banyak faktor, baik yang berasal dari dalam diri siswa (intern) maupun dari luar diri siswa (ekstern). Kedisiplinan siswa dipandang sebagai salah satu faktor yang mempengaruhi hasil belajar siswa. Kedisiplinan siswa adalah keadaan sikap atau perilaku siswa yang sesuai dengan aturan atau tata tertib yang berlaku sehingga tercipta ketertiban dan keteraturan di sekolah maupun saat di rumah. Dengan adanya kedisiplinan yang berdasarkan dorongan dan kesadaran yang muncul dalam diri siswa serta dilakukan secara teratur tanpa adanya paksaan atau tekanan dari pihak manapun akan membentuk kedisiplinan yang permanen.

Kedisiplinan merupakan suatu sikap yang perlu dimiliki oleh setiap siswa. Dengan disiplin, diharapkan segala kegiatan yang telah terstruktur dapat terlaksana dengan baik dan mendapatkan hasil yang baik. Dalam belajarpun, siswa perlu memiliki kedisiplinan demi tercapainya keberhasilan belajar, baik di rumah maupun di sekolah. Apabila dalam diri siswa sudah tertanam kedisiplinan yang baik, maka ketekunan dan kepatuhannya akan terus meningkat sehingga membuat hasil belajarnya meningkat. Sebaliknya, 
apabila siswa belum mampu menanamkan kedisiplinan yang baik, maka ketekunan dan kepatuhannya juga kurang baik sehingga berdampak pada hasil belajarnya. Kedisiplinan siswa meliputi disiplin berangkat sekolah, disiplin mengikuti pembelajaran di kelas, disiplin mengerjakan tugas, disiplin belajar di rumah dan disiplin menaati tata tertib sekolah.

Dalam penelitian ini akan membahas pengaruh kedisiplinan siswa terhadap hasil belajar siswa. Gambar kerangka berpikir sebagai berikut.

Kedisiplinan (X)

Indikator:

1. Disiplin berangkat sekolah.

Disiplin mengikuti pembelajaran di kelas.

3. Disiplin mengerjakan tugas.

4. Disiplin belajar di rumah.

5. Disiplin menaati tata tertib sekolah.

Hasil Belajar Siswa

(Y)

Dilihat dari hasil nilai UTS siswa semester genap tahun 2020/2021

Dari gambar kerangka berpikir tersebut terdapat dua variabel di dalamnya, yaitu:

1. Variabel Independen (Variabel Bebas)

Yaitu variabel yang mempengaruhi atau yang menjadi sebab perubahannya atau timbulnya variabel terikat. Variabel independen pada penelitian ini adalah kedisiplinan (X).

2. Variabel Dependen (Variabel Terikat)

Yaitu variabel yang dipengaruhi atau yang menjadi akibat karena adanya variabel bebas. Dalam hal ini yang menjadi variabel terikat adalah hasil belajar siswa (Y).

\section{Hipotesis}


Berdasarkan uraian di atas, maka dapat dirumuskan hipotesis sebagai berikut.

$\mathrm{H}_{0}$ : Tidak terdapat pengaruh yang signifikan kedisiplinan terhadap hasil belajar siswa Sekolah Dasar Negeri Kassi Kecamatan Manggala Kota Makassar. 


\section{BAB III \\ METODOLOGI PENELITIAN}

\section{A. Desain Penelitian}

Jenis penelitian ini adalakah kuantitatif dengan metodeex post facto. Penelitian ex post facto sering disebut dengan after the fact artinya penelitian yang dilakukan untuk mengetahui penyebab-penyebab terhadap peristiwa yang sudah terjadi

Darmadi menyatakan bahwa " penelitian ex post facto merupakan penelitian dimana variabel-variabel bebas telah terjadi ketika peneliti memulai memulai dengan pengamatan variabel terikat dalam suatu penelitian. "Sedangkan, jenis penelitian ini menggunakan jenis penelitian kuantitatif, karena data yang diperoleh dianalisis sesuai metode statistik yang digunakan kemudian diinterpretasikan.

Dalam penelitian ini, peneliti melakukan penelitian tentang pengaruh kedisiplinan siswa terhadap hasil belajar siswa di SD Negeri Kassi Kecamatan Manggala Kota Makassar.

Pada penelitian ini terdapat satu variabel bebas (independen) dan satu variabel terikat (dependen).

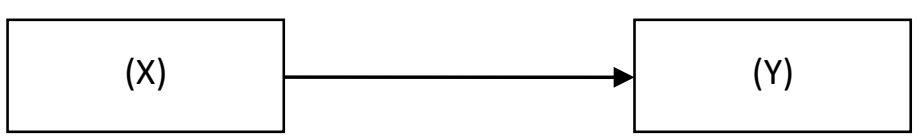

Keterangan:

$\mathrm{X}$ : Kedisiplinan

Y : Hasil belajar siswa

\section{B. Populasi dan Sampel}

1. Populasi

Arikunto dalam Riduwan mendefinisikan populasi sebagai keseluruhan subjek penelitian.Sedangkan menurut Sugiyono dalam 
Riduwan, "populasi adalah wilayah generalisasi yang terdiri atas objek/subjek yang mempunyai kuantitas dan karaktristik tertentu yang ditetapkan oleh peneliti untuk dipelajari dan kemudian ditarik kesimpulannya".

2. Populasi

Sampel penelitian adalah sebagian dari populasi yang diambil sebagai sumber data dan dapat mewakili seluruh populasi. Oleh karena itu, agar sampel yang diambil dapat representatif perlu memberlakukan teknik sampling. Teknik yang digunakan dalam penelitian ini adalah teknik random sampling, menurut Sugiyono, "Teknik random sampling merupakan cara pengambilan sampel secara acak sehingga memberikan kesempatan yang sama bagi setiap anggota populasi untuk dipilih menjadi anggota sampel."

Pengambilan sampel menggunakan rumus proporsional random sampling menurut Sugiyono yang dikutip oleh Riduwan yaitu:

Keterangan:

ni $=$ jumlah sampel setiap sekolah

$\mathrm{n}=$ jumlah sampel seluruhnya

$\mathrm{Ni}=$ jumlah populasi setiap sekolah

$\mathrm{N}=$ jumlah populasi seluruhnya

\section{Variabel penelitian}

Sugiyono menjelaskan bahwa "variabel penelitian adalah segala sesuatu yang berbentuk apa saja yang ditetapkan peneliti untuk dipelajari sehingga diperoleh informasi tentang hal tersebut, kemudian ditarik kesimpulannya". Dalam penelitian ini variabel yang digunakan yakni variabel independen dan variabel dependen.

1. Variable Independen

Variabel independen sering disebut sebagai variabel bebas. Sugiyono mengemukakan bahwa "variabel independen merupakan variabel yang mempengaruhi atau yang menjadi sebab perubahannya 
atau timbulnya variable dependen (terikat).Variabel independen dalam penelitian ini yaitu kedisiplinan (X).

2. Variable Dependen

Variabel dependen sering disebut sebagai variabel terikat. Menurut Sugiyono, "variabel dependen adalah variabel yang dipengaruhi atau yang menjadi akibat, karena adanya variable bebas". Dalam penelitian variabel dependennya yaitu hasil belajar siswa $(\mathrm{Y})$.

\section{Definisi Operasional}

Definisi operasional digunakan untuk menyamakan persepsi antara peneliti dengan pembaca terhadap variabel yang digunakan dalam penelitian, sehingga diharapkan dapat menghindari kekeliruan maksud dan tujuan yang ingin dicapai.

1. Variable Kedisiplinan (X)

Kedisiplinan siswa adalah keadaan sikap atau perilaku siswa yang sesuai dengan aturan atau tata tertib yang telah berlaku sehingga tercipta ketertiban dan keteraturan. Kedisiplinan siswa dalam penelitian ini meliputi: a) Disiplin berangkat sekolah. b) Disiplin mengikuti pembelajaran di kelas. c) Disiplin mengerjakan tugas. d) Disiplin belajar di rumah. e) Disiplin menaati tata tertib sekolah.

2. Variable Hasil Belajar Siswa (Y)

Hasil belajar siswa merupakan perubahan tingkah laku dan sikap pada siswa setelah melakukan kegiatan belajar. Hasil belajar yang diperoleh individu yaitu berupa pengetahuan, keterampilan dan sikap yang ketiganya termasuk dalam tiga ranah. Ketiga ranah tersebut adalah ranah kognitif, afektif dan psikomotorik.

\section{E. Teknik Pengumpulan Data}

Ada beberapa macam teknik pengumpulan data yang digunakan dalam suatu penelitian.Teknik pengumpulan data yang digunakan dalam 
penelitian ini yaitu dengan kuesioner (angket). Uraian selengkapnya sebagai berikut.

1. Kuesioner (angket)

Sugiyono mendefinisikan kuesioner atau angket sebagai teknik pengumpulan data yang dilakukan dengan cara memberi seperangkat pertanyaan atau pernyataan tertulis kepada responden untuk dijawabnya.

2. Dokumentasi

Dokumentasi berasal dari kata dokumen yang artinya barangbarang tertulis. Riduwan) menyatakan bahwa dokumentasi ditujukan untuk memperoleh data langsung dari tempat penelitian, meliputi bukubuku yang relevan, peraturan-peraturan, laporan kegiatan, foto-foto, film dokumenter, data yang relevan penelitian.

Arikunto berpendapat dokumentasi digunakan untuk mencari data mengenai hal-hal atau variabel yang berupa, catatan, transkrip, buku, surat kabar, majalah, prasasti, notulen rapat, lengger, agenda, dan sebagainya. Pada penelitian ini, peneliti menggunakan nilai ulangan tengah semester sebagai sumber untuk mengetahui hasil belajar siswa.

\section{F. Instrumen Penelitian}

Dalam sebuah penelitian, dibutuhkan instrumen penelitian sebagai alat untuk memperoleh data penelitian. Instrumen penelitian digunakan untuk mengukur nilai variabel yang akan diteliti. Dalam melakukan penelitian, seorang peneliti harus menggunakan sebuah alat ukur yang baik, yang disebut dengan instrumen penelitian. Instrumen yang digunakan dalam penelitian ini yaitu angket atau kuesioner.

Pada penelitian instrumen yang digunakan yaitu angket. Responden diminta untuk memberi tanda ceklis $(\sqrt{ })$ pada kolom yang tersedia sesuai dengan keadaan yang sebenarnya. Dan penelitian ini menggunakan skala likert dengan rentang 4

1. Validasi Angket 
Menurut Riduwan menjelaskan bahwa validitas adalah suatu ukuran yang menunjukkan tingkat keandalan atau kesahihan suatu alat ukur.Uji validitas digunakan untuk mengukur valid tidaknya kuesioner yang akan digunakan.

2. Rehabilitas Angket

Uji reliabilitas dilakukan untuk mendapatkan tingkat ketepatan (keterandalan atau keajegan) instrumen yang digunakan.

\section{G. Pengelolaan dan Analisis Data}

1. Statistik Data Deskriptif

Deskripsi data dilakukan dengan analisis deskriptif terhadap variabel- variabel penelitian, baik variabel bebas maupun variabel terikat. Statistik deskriptif adalah statistik yang berfungsi untuk mendiskripsikan atau memberi gambaran terhadap obyek yang diteliti melalui data sampel atau populasi sebagaimana adanya, tanpa melakukan analisis dan membuat kesimpulan yang berlaku untuk umum. Analisis statistik deskriptif digunakan untuk mengetahui gambaran umum mengenai variabel kedisiplinan siswa (X). 


\section{DAFTAR PUSTAKA}

Nokwari. 2013. Pengaruh Tingkat Disiplin dan Lingkungan Belajar di Sekolah terhadap Prestasi Belajar Siswa. Ekonomi. (Online). Vol 1 No. 2.

Khafid, Muhammad dan Suroso. 2007. Pengaruh Disiplin Belajar dan Lingkungan Keluarga terhadap Hasil Belajar Ekonomi. Jurnal Pendidikan. (Online). Vol 2 No 2.

Imam Alimaun. Skripsi. Pengaruh Kedisiplin Terhadap Hasil Belajar Siswa Kelas V Sekolah Dasar Se-Binaan R.A Kartini Kecamatan Kutoarjo Kabupaten Sidoardjo.

Jusmawati, J., Satriawati, S., \& Irmam, R. (2018). Pengaruh motivasi beraviliasi terhadap keaktifan belajar matetatika siswa SD Impres Perumnas Antang Kota Makassar. JPRD Jurnal Riset Pendidikan Dasar) 1(2), 158-165.

Nur Fajar, Skripsi. Pengaruh Lingkungan Sekolah terhadap Kedisiplinan Belajar Siswa Kelas V SD Inpres Borong Jambu II Kota Makassar Tahun Pelajaran 2019/2020.

Nurmalasari panjaitan, Skripsi. Pengaruh Kedisiplinan Terhadap Hasil Belajar Siswa Mis Al Manar Tembung Kecamatan Percut Sei Tuan Kabupaten Deli.

Pespi Helina, Skripsi. Pengaruh Kedisiplinan Siswa Terhadap Hasil Belajar Paidi Smp Budi Mulia Kota Bengkulu Tahun Pelajaran 2019/2020.

Jarot Andi Wibisono Skripsi. Pengaruh Kedisiplinan Belajar Terhadapprestasi Belajar Pendidikan Agama Islamsdn Ngajaran 03 Kec. Tuntang Kab. Semarang

Adawiyah, W., Basri, M., \& Nur, H. (2017). Pengaruh Kedisiplinan Belajar Terhadap Prestasi Belajar Murid Kelas V SD Negeri Sumanna Kecamatan Tamalate Kota Makassar. JKPD (Jurnal Kajian Pendidikan Dasar). 
